\title{
EDUCATIONAL UTILIZATION OF NARRATIVE MEDICINE IN KOREAN MEDICAL SCHOOLS
}

\author{
Youngsub Oh \\ Department of Multicultural Education, Inha University (South Korea)
}

\begin{abstract}
The purpose of this study is to explore current status and future task of educational utilization of medical humanities, focusing on narrative medicine in Korea. For this end, firstly, this study reviewed Korean research literatures on medical humanities. Second, this study reviewed the educational utilization of narrative medicine in medical education and humanities education in Korea. Lastly, this study provided the implication and future task for education and research. This study is expected to be a useful reference for developing teaching and learning model to nurture medical professionals, counselors and therapists, and researchers.
\end{abstract}

Keywords: Medical humanities, narrative medicine, narrative, current status, teaching model.

\section{Introduction}

Narrative, as a basic element of humanities, has been expanding and transforming beyond humanities toward various fields such as culture, economy, education, information industry, and tourism (Kim, 2011). This trend is a global phenomenon that is called a "narrative turn". Narrative has emerged as a very noteworthy force in counseling and psychotherapy, and even in the medical field. Academic fields such as narrative therapy and narrative medicine have already begun to be established in North America and Europe. Narrative-based materials has been utilized in educational fields, and medical research on clients from various backgrounds has been in progress (Oh et al., 2018).

Although South-Korea is relatively a late comer in the field of narrative-based therapeutic industry, there has been recently a rapid movement of convergence between narrative and therapy in the areas of medicine, humanities, and social sciences.

Interestingly, those medical schools and the humanities and social sciences schools respectively have different focus on utilizing narrative (Kim \& Oh, 2020). Medical schools pay attention to cultivating the narrative competence of medical personnel. In contrast, focusing on narrative's therapeutic nature, humanities and social sciences schools pay attention to the clinical utilization of narratives. In this regard, that difference implies how to compensate for the shortcomings of each educational institution. In other words, those medical schools lack interest in the therapeutic nature of narrative itself, and the humanities and social sciences schools lack interest in the cultivation for counselors and therapists with narrative competence. Therefore, both educational institutions need to learn each other's strengths in utilizing narratives in education and research to compensate for their own weaknesses.

\section{Research methods}

This study adopted literature research method. Research procedure is as follow:

First, Data Collection. Two keywords such as narrative medicine and medical humanities were used to search all papers and theses in Research Information Sharing Service (RISS, 2020). As a result, 27 papers, including 15 journal articles, 4 dissertations, and 8 research papers, were finally collected with the search word of narrative medicine. And 50 papers, including 39 journal articles, 1 dissertation, and 10 research papers, were finally collected with the search word of medical humanities. Those papers have been published between 2009 and 2020. Thus, 2009 was the first year of publication of medical humanities research in Korea.

Second, Selection. Among 27 papers with the theme of narrative medicine and 50 papers with the theme of medical humanities, this study finally selected those papers with focus on educational utilization. The number of those final papers were totally 22. Those selected papers were divided with two groups like medical education and humanities and social science education.

Third, Analysis. This study analyzed 13 papers to explore medical education's trend and characteristics of educational utilization. As well, implications and future research agendas were suggested, based on the analysis of trend from medical education. 


\section{Educational utilization of narrative medicine in Korean medical schools}

The number of medical humanities class has been increasing recently in Korean universities. However, there are still more medical schools that do not have any medical humanities coursework, and even if that coursework is opened, adjunct professors take on the role and medical professors without the relation of medical humanities are in charge of medical humanities education in most of Korean medical schools (Kim, 2019).

According to the current status in Korean medical schools in 2019 (Kim, 2019), there are 41 medical schools and medical graduate schools. Among these schools, only 24 schools $(59 \%)$ have medical humanities coursework or related coursework, but only 14 schools $(34 \%)$ have employed professors majoring in humanities. Moreover, 11 schools (27\%) have employed professors majoring in medical humanities. The lack of human resources in dental schools in Korea was more serious. There are only 3 schools with medical humanities coursework or related coursework, but only 2 professors with humanities majors and 1 professor with medical humanities major.

In this current situation, educational utilization of narrative medicine in Korean medical areas is evaluated to be still in its infancy than that area in the United States. Researches in narrative medicine or narrative-based education in Korean medical humanities classes have begun since 2006. Those researches are summarized as the following Table 1:

Table 1. Narrative Medicine Research in Korean Medical Areas.

\begin{tabular}{|c|c|c|c|}
\hline No. & Research Results & Educational Implications & Researchers \\
\hline 1 & \multirow{2}{*}{$\begin{array}{l}\text { Absence of educational goal } \\
\text { as a prerequisite of medical } \\
\text { humanities education }\end{array}$} & \multirow{2}{*}{$\begin{array}{l}\text { Necessity of curriculum and educational } \\
\text { model development, cultivation of } \\
\text { professors }\end{array}$} & Meng (2007) \\
\hline 2 & & & An et al (2008) \\
\hline 3 & $\begin{array}{l}\text { Three ways of writing } \\
\text { education }\end{array}$ & $\begin{array}{l}\text { Writing as an essence of education, } \\
\text { especially writing for communication }\end{array}$ & Shin (2006) \\
\hline 4 & $\begin{array}{l}\text { Characteristics of discussion } \\
\text { materials }\end{array}$ & $\begin{array}{l}\text { Necessity to reflect medical students' } \\
\text { characteristics }\end{array}$ & Ahn \& Jeon (2011) \\
\hline 5 & $\begin{array}{l}\text { Analysis of a class of } \\
\text { 'Writing for Healing' }\end{array}$ & $\begin{array}{l}\text { Necessary to redefine healing in terms of } \\
\text { holism and }\end{array}$ & Ban \& Yeh (2012) \\
\hline 6 & $\begin{array}{l}\text { Analysis of creative strength } \\
\text { and weakness of medical } \\
\text { students }\end{array}$ & $\begin{array}{l}\text { Necessary to develop curriculum based } \\
\text { on medical students' characteristics and } \\
\text { design-based thinking }\end{array}$ & Hyun (2013) \\
\hline 7 & $\begin{array}{l}\text { Three ways of writing } \\
\text { education }\end{array}$ & $\begin{array}{l}\text { Necessity of reflective, imaginative and } \\
\text { empathic writing }\end{array}$ & Hwang (2013) \\
\hline 8 & $\begin{array}{l}\text { Current status of medical } \\
\text { communication classes }\end{array}$ & $\begin{array}{l}\text { Necessity to develop those curriculum } \\
\text { and diversification of lecture contents }\end{array}$ & Lee et al (2015) \\
\hline 9 & $\begin{array}{l}\text { Analysis of poem writing } \\
\text { class }\end{array}$ & $\begin{array}{l}\text { Possibility of poem as a tool to } \\
\text { communicate between patients and } \\
\text { doctors and as a tool of treatment }\end{array}$ & $\operatorname{Kim}(2016)$ \\
\hline 10 & $\begin{array}{l}\text { Confusion of its educational } \\
\text { purpose, procedure and } \\
\text { contents }\end{array}$ & $\begin{array}{l}\text { Improvement of ethical problem-solving } \\
\text { competency based on critical thinking } \\
\text { and academic writing }\end{array}$ & Jeon \& Ahn (2017) \\
\hline 11 & $\begin{array}{l}\text { Application of Korean novel } \\
\text { literary text with illness } \\
\text { narrative to moral } \\
\text { imagination education in a } \\
\text { nursing school }\end{array}$ & $\begin{array}{l}\text { Meaningful growth of nursing students } \\
\text { as moral subject through narrative } \\
\text { medicine }\end{array}$ & Hwang \& Kim (2017) \\
\hline 12 & $\begin{array}{l}\text { Application of flipped- } \\
\text { learning- based class }\end{array}$ & $\begin{array}{l}\text { Possibility of flip learning as a new } \\
\text { teaching strategy and as a way to } \\
\text { strengthen competencies }\end{array}$ & Oh (2020) \\
\hline 13 & $\begin{array}{l}\text { Importance of self-reflective } \\
\text { writing and identity as a } \\
\text { 'listening doctor' }\end{array}$ & $\begin{array}{l}\text { Suggestion of } 3 \text { kinds of writings: } \\
\text { oneself, patients, and patients' family }\end{array}$ & Youm (2020) \\
\hline
\end{tabular}

Korea.

First, at the beginning stage, general directions of medical humanities education were explored in

Meng (2007) suggested general future tasks for medical humanities in Korea. He evaluated that the current status of Korean medical humanities was twenty years later than the United States. And he called for firstly setting up general educational purpose based on humanistic virtue, and then developing 
interdisciplinary curriculum and educational models, and finally cultivating medical-humanities-majoring professors and prepare a related system.

An et al (2008) analyzed the syllabi of medical humanities and social sciences classes in 10 medical schools. As a result, there was some commonality in 10 schools like emphasis on disease prevention, health improvement, medical ethics, medical regulation, professionalism, and community medicine. Future tasks were suggested as the clarification of educational goals in order to develop a core curriculum of medical humanities and social sciences in Korea and then the shared experiences of developing a well-designed curriculum with other medical schools for effective teaching.

Second, specific ways of narrative medicine or narrative-based education in Korea have been discussed afterwards.

Shin (2006) suggested the need for writing education for medical students. When considering Korean medical schools' conditions, the writing education in medical schools can be conducted in three ways as follows : writing as a study tool, writing focused on appropriate medical sentences, and writing for communication. The author suggested the third way of writing education in more realistic way to Korean circumstances.

Ahn \& Jeon (2011) analyzed the characteristics of discussion materials such as book and movie that promote student participation in discussions, satisfaction with student instruction, and tutor intervention in a medical university's medical humanities class in Korea. Research result said that differences in grades and the understanding of the discussion material should be considered when choosing discussion materials. Thus, it implies the necessary to develop medical humanities discussion's materials reflecting medical students' situations and characteristics.

Ban and Yeh (2012) provided cases of writing activity at ' $Y$ ' medical school. Writing activities were done in a part of medical humanities class or extracurricular activities class with independent writing class. Especially, a class of 'Writing for Healing' opened to pre-medical freshmen. Although the class aimed to help students identify and acknowledge internal diseases to lead a healthier life and eventually become positive and responsible health care providers, the term of healing was still vaguely defined in the medical class. The researchers suggested the necessary to approach healing in terms of holism.

Hyun (2013) analyzed creative strength and weakness of medical college students through TTCT (Torrance Tests of Creative Thinking), and thus said that those students had storytelling articulateness as a strength but lack of idea production or imagination and lack of understanding of other thoughts and inner image. Therefore, medical humanities curriculum needs to be developed on the basis of medical students' characteristics and design-based thinking.

Hwang (2013) suggested the utilization way of illness narrative in teaching medical humanities. First, reflective writing on medical care provider's own inner world or educational experience was the most necessary. Second, imaginative and empathic writing on patients' emotional condition and their context with a concrete plot was helpful. Third, parallel chart writing, which was developed by Rita Charon (2008), can be written by medical students or medical professionals with everyday language in order to understand the perspective of patients and externalize medical professionals' ambiguous emotions.

Lee et al (2015) examined the current status of medical communication classes of medical schools in Korea like the existence of those classes, course title, total hours, and institution. The result was that many medical schools in Korea are evaluated to be at the beginning stage of developing and operating the curriculum to teach medical communication. Thus, as the status was not systematic, the study suggested the need for seriously developing and operating curriculum focused on medical communication, and the need for diversification of lecture contents in Korea.

Kim (2016) said that writing poem may change pre-medical students' introspection and the experience could provide mechanism to practice clinical treatment for reducing pain of body and mind of the patients. According to the Kim's research and analysis for 88 students to participate poem and literature class in reading and writing poems during 4 semesters, positive awareness for poetry increased from $37 \%$ to $76 \%$, while negative awareness decreased from $46 \%$ to $11 \%$. Pre-medical students recognized that poems can be used as a tool to communicate between patients and doctors and when students become doctors, poems can be as a tool of treatment.

Jeon \& Ahn (2017) said that the reason for the difficulty in teaching medical ethics and professionalism in Korea lies in the confusion of its educational purpose, educational procedure and contents. The improvement of ethical problem-solving competency needs to be the core component in teaching medical ethics and professionalism. Therefore, the moral and ethical inference in medical ethics must be based on critical thinking and academic writing.

Hwang and Kim (2017) applied Korean novel literary text with illness narratives to moral imagination education in a nursing school. The education was meaningful to nursing students in that they can grow up to moral subject with serious thought and creative activity and self-reflection. The educational experience can be cognitive and emotional basis for health care providers. 
Oh (2020) said that there were not yet effective teaching and learning models to realize the purpose of medical humanities education. In this regard, exploring the possibility of flipped-learning to apply medical humanities classes, the study designed the class based on the ADDIE model consisting of five stages, analysis - design - development - execution - evaluation. And finally the study applied flipped-learning-based medical humanities class to ' $\mathrm{P}$ ' university's medical school and analyzed the recognition of learners.

Youm (2020) said that primary writing needs to be self-reflective writing as a process of understanding oneself first in order to understand one's own body and those of others. And then defining medical professional's identity as a 'listening doctor', the researcher said that writing needs to focus on listening. For this end, the educational content has been suggested as following three kinds of writings: writing about medical professional's own experiences with illness, writing about the situation of a patient as the main agent of sickness, and writing on a patient's family as the main agent of caregiving.

\section{A Case of narrative-medicine education in a medical school}

The 'I' University's medical school was established in 1984 in 'I' city with the third largest population in Korea. The medical school have cultivated approximately 50 medical doctors and 100 nurses a year. The medical school have employed a professor with medical humanities major and operated the curriculum of medical humanities. The curriculum of medical humanities consists of three stages and seven coursework as the following Table 2.

Table 2. Medical Humanities Education in a Medical School.

\begin{tabular}{|c|c|c|c|c|}
\hline Stage & Coursework & Education Content & \multicolumn{2}{|c|}{ Academic Grade } \\
\hline \multirow{2}{*}{1} & Patient-Physician-Society 1 & Life-Science-Ethics & \multirow{2}{*}{ Pre-medical $2^{\text {nd }}$ grade } & $1^{\text {st }}$ Semester \\
\hline & Patient-Physician-Society 2 & Communication Skills & & $2^{\text {nd }}$ Semester \\
\hline \multirow{3}{*}{2} & Patient-Physician-Society 3 & Medicine and Arts & Medical $1^{\text {st }}$ grade & $2^{\text {nd }}$ Semester \\
\hline & Patient-Physician-Society 4 & Medical History & \multirow{2}{*}{ Medical $2^{\text {nd }}$ grade } & $1^{\text {st }}$ Semester \\
\hline & Patient-Physician-Society 5 & Medical Interview & & $2^{\text {nd }}$ Semester \\
\hline \multirow{2}{*}{3} & Patient-Physician-Society 6 & Medical Ethics & \multirow{2}{*}{ Medical $4^{\text {th }}$ grade } & $1^{\text {st }}$ Semester \\
\hline & Patient-Physician-Society 7 & Career Exploration & & $2^{\text {nd }}$ Semester \\
\hline
\end{tabular}

As the coursework name 'Patient-Physician-Society (PPS)' means, that coursework focus on a variety of issues within the relationship between patient and medical professionals, between medical professionals and society.

At the first stage, the PPS- 1 cultivates those $2^{\text {nd }}$ grade pre-medical students to have ethical issues in life science areas like personal information protection, climate crisis, genetically modified organism, abortion, Dr. Hwang woo-suk scandal in human stem cell research, medical experiment crime by Japanese Army Unit 731, operation room's closed-circuit television, and so on. These are important medical ethics issues in Korea. And then the PPS-2 cultivates those students to have interpersonal communication skills in studying self-perception, cultural diversity, listening and responding, verbal and nonverbal communication.

At the second stage, the PPS-3 cultivates those first and second grade medical students to have empathic competence through arts like literature, visual arts, and cultural relics. Moreover, the PPS-4\&5 make those students to recognize medical professionalism human right sensitivity toward minority groups through western and Korean medical history, and to learn medical interview skills and practices in various medical cases.

At the third stage, the PPS-6\&7 cultivates those third and fourth grade medical students to seriously consider their roles as medical professionals with ethical knowledge and attitude before their graduation and entrance to medical fields.

\section{Conclusion and discussion}

The above researches don't describe everything of narrative medicine education but present overall picture in Korean medical schools. However, those researches imply future task of narrative medicine or medical humanities education in Korean medical schools, especially during and after Covid-19 pandemic era.

First, current education has generally emphasized on writing education in Korea. This trend seems to reflect a natural result from Korean medical humanities education's short history. Although writing is a core element of narrative medicine education, educators need to try other education areas beyond writing, other various means of expression beyond narrative (Hwang, 2020a). Narrative medicine curriculum can be developed with medium like drama, movie, music, etc. 
Second, existing tendency of narrative utilization focus mainly on acquiring patient's information and forming rapport with patients. In other word, narrative medicine has been not used as a critical tool to fundamentally reconsider the role of medicine and medical professionals but mainly used as a complementary tool for medicine (Hwang, 2020a). In this sense, narrative medicine needs to be much more sought as a critical means of medical education. Especially, medical humanities or narrative medicine needs to seriously consider the unprecedented health crisis like the current Covid-19 pandemic. Hwang (2020b) said that social justice of national immunity system or ecological system beyond the existing human-centered health perspective are requested to be seriously consider and responded as medical humanities and narrative medicine's issues. Thus, medical humanities education can raise up medical professionals with critical perspectives and alternative solutions to existing medical situations.

Third, medical narratives need to be educated and studied in bi-directional ways. Hwang (2020a) suggested the necessity to introduce specific education and research on how to connect closely patient's illness narratives and doctor's medical narratives, and to improve the existing medical customs like writing medical charts in clinical fields. Thus, medicine humanities education and research in Korea need to focus on narrative itself like narrative's therapeutic mechanism and effect.

\section{References}

Ahn, J. H. \& Jeon, W. T. (2011). Analysis of the characteristics of discussion materials that promote group discussion in the medical humanities. Korean Journal of Medical Education, 23(4), 253-261.

An, J. H., Kwon, I., Lee, S. N., Han J. J., \& Jeong J. E. (2008). Study on the medical humanities and social sciences curriculum in Korean. Korean Journal of Medical Education, 20(2), 133-144.

Ban, J., \& Yeh, B. I. (2012). Application of 'writing for healing' in premedical humanities education. Korean Journal of Medical Education, 24(3), 189-196.

Charon, R. (2008). Narrative medicine: Honoring the stories of illness. Oxford University Press.

Choi, K. J. (2020) 2020-1st semester online lecture excellent case guide book, 55-58.

Hwang, H. S., \& Kim, S. A. (2017). Moral imagination education using illness narrative literature. Korean Journal of General Education, 11(3), 153-183

Hwang, I. K. (2013). Teaching medical humanities through an illness narrative. Korean Journal of Medical Education, 25(2), 81-88.

Hwang, I. K. (2020a). Narrative in medicine, focusing on current status and tasks. Humanities Research, $45,435-464$.

Hwang, I. K. (2020b). Covid-19 and medical humanities: Medical humanities' history and tasks. Writers, $74,183-196$.

Hyun, E. (2013) Analyzing the creative strengths of college students majoring in medicine for developing 'medical humanities' based on design. Journal of Korea Design Knowledge, 26, 249-258.

Inha University's College of Medicine (2020). Introduction of the college: purpose of education. Retrieved March 1, 2021, from http://dept.inha.ac.kr/user/indexSub.do?codyMenuSeq=9505\&siteId=medicineeng

Jeon, D. S., \& Ahn, D. S. (2017). Teaching medical ethics and professionalism based on critical thinking and writing. Journal of Humanities, 67, 157-193.

Kim, J. H. (2019). Expansion of narrative medicine through re-reading and re-writing: Becoming physician-interpreter (Unpublished Doctoral Dissertation), Pusan National University, Korea.

Kim, S. L. (2016). A medical-humanistic study of poem and medical education. Cogito, 79, 348-374.

Kim, Y. S. (2011). Social and cultural expansion and transformation of storytelling. Seoul: Book Korea.

Kim, Y. S., \& Oh, Y. S. (2020). A qualitative case study on introducing the teaching model of narrative-based humanities therapy. Korean Education Inquiry, 38(1), 107-130.

Lee, I. W., Kim, C. S., Lee, H. S., \& Lee, W. S. (2015). A content analysis on a form and manner in medical communication subject: Focused on the medical schools in Korea. Communication Theories, 11(2), 104-141.

Meng, K. H. (2007). Teaching medical humanities in Korean medical schools: Tasks and prospect. Korean Journal of Medical Education, 19(1), 5-11.

Oh, H. J. (2020) A case study on application of flipped learning in medical humanities: Focus on instructional design and learners' perspective. Journal of Science Education, 44(2), 240-258.

Oh, Y. S., Kim, Y. S., \& Wang, G. M. (2018). Exploratory study on international research trend of narrative therapy. Journal of Literary Therapy, 48, 41-74.

RISS (2020). Research Information Sharing Service. Retrieved March 1, 2021, from http://www.riss.kr/index.do

Shin, S. K. (2006) The need for writing education for medical students and its direction. The Research in Writing, 2, 61-84

Youm, W. H. (2020). The direction and composition of medical writing. The Korean Journal of Literacy Research, 11(1), 301-325. 